\title{
Value Perplexities between Education and Money: The Phenomenon of Failing Students within Rural Areas in East Java
}

\author{
Agung Winarno \\ Department of Management, Faculty of Economic Universitas Negeri Malang \\ E-mail: agung.winaro.fe@um.ac.id
}

\begin{abstract}
This study aims at unraveling the phenomenon of failing students and developing an entrepreneurship education pertinent to the potency and experiences of the targeted failing students. This study used descriptive qualitative approach and education development design targeted the failing students who decline their secondary school within Blitar Regency East Java. The results of this study showed that the phenomenon of failing students occurs on account of the economic development within the rural areas. In other words, it can be affirmed that economic development depreciates the important of education. In addition, the social and culture within the circumstance as well as the availability of education institution influence the concern of those failing students in pursuing education.
\end{abstract}

Keywords: Failing students, rural economic development, entrepreneurship education

\section{INTRODUCTION}

Failing student is a situation where children are neglected due to the attitude of parents who do not give a proper attention to the process of ddevelopment of the child regardless of the rights - the right of children to receive a proper education. The constitution No. 4 of 1979, the abandoned children is defined as a child whose parents for some reasons, are not able to meet the needs of the child, therefore, the child is abandoned and neglected. According to the Constitution number 23 of 2002 that the neglected and abandoned children are children whose needs are not being fulfilled appropriately in terms of physical, mental, spiritual and social.

Education is a fundamental right for children. Rights which must comply with at least the cooperation of parents, educational institutions, and governments. Education will be able to be realized if all the components (parents, community organizations, educational and the government) are willing to support the process of education. Sipitanou and Papagiannis (2013:143) clarifiy, that the educational process affects the business option, which in turn plays a key role in economic growth, competitiveness, innovation and productivity. To achieve higher levels of innovation and economic growth is necessary to promote entrepreneurship.

Education is the responsibility of all layers of the society, not just the responsibility of the school. Consequently, all citizens have a moral obligation to preserve education. Thus, when there are community members who do not go to school simply because they had no money, the prosperous or relatively wealthy society have a moral obligation to become a foster parent for the continuation of failing students in which the number reaches tens of millions of children across Indonesia.

Education essentially started from the family. This paradigm is important to be understood by all parents to shape the human character of this nation's future. The family is first and prominent environment recognized by a child, even since the child in the womb. Therefore, education in the family which enlighten and construct the character of the pious and creative capital is imperative to children's success in the future. Subsequently, failing students create juvenile delinquency such as brawl, racing on highway, drunk habits and fight as well as the other consequences such as feelings of inferiority and low self-esteem.

One solution to overcome the prevalent social impact of failing students is by giving them a nonformal education in the form of the entrepreneurship development based on their experience and concerning on its simplicity, practicality, effectiveness, and efficiency. The phenomenon of failing students and economic development of the rural area in a one-sided performs as the issue of low interest in formal school within the children. On the other side, this plays as a potential for the development of non-formal education in the form of practical training oriented on the formation of young rural entrepreneurs. Although general education plays a key role in the development of entrepreneurship, the most important variable for entrepreneurial flourishing and 
prosperity is entrepreneurial education, which involves a more limited educational condition (Sipitanou and Papagiannis, 2013:143).

The outmoded paradigm stated that entrepreneurship is an innate talent has been changing into a new paradigm argues that entrepreneurship is a science that can be learned. Kuratko (2003: 11-12) states that "The entrepreneurial mystique? It's not magic, it's not mysterious, and is has nothing to do with the genes. It's a discipline. And, like any discipline, it can be learned. "

Entrepreneurship education can be used as a medium in the process of forming a prodigious agent of change in all sectors. Indeed, not everyone should be an entrepreneur to feel the benefit of entrepreneurship education, but everyone needs to be more entrepreneurial. Entrepreneurship education is education that applies the principles and methodologies towards internalization of the values of entrepreneurship in their students through an integrated curriculum. Hansemark (1998) asserts that the main purpose of entrepreneurship education is to develop the skills, knowledge, and the creation of new characters that are important to entrepreneurial activity. Thus entrepreneurship education should be able to form selfemployment by increasing knowledge of the business and formed psychological attributes such as confidence, self-esteem, and self-efficacy.

Entrepreneurship itself aims at performing as a business where a person has the ability to think creatively and innovatively to create something new and different, particularlyadvantageous for the people around them. Many people are either entrepreneurs or not entrepreneurs who obtain their own success by thinking creatively and innovatively. Consistently, innovative and creative thinking ability will spark new ideas and different that has not been previously unthinkable by people. Lubis (2014: 546) also stated, "In short, people will need to be creative, rather than passive; capable of self-initiated action, rather than dependent; they will need to know how to learn, rather than expect to be taught; they will need to be enterprising in their outlook, not think and act like an employee or client. The organisations in which they work, communities in which they live and societies in which they belong, will in turn, also need to possess all these qualities".

In Indonesia, entrepreneurial start growing as the development of the times. It is commonly found that many entrepreneurs started his career from zero and eventually become successful. Entrepreneurship reachesall layers of people, both the young and old people. The progress of the times and technology enables their motivation to always work better. Children and students can take advantage of everything in accordance with the knowledge they gained from both the school and outside of school.However, this does not apply to failing students. Failing student is a situation where children are neglected and abandoned due to the attitude of parents who do not give proper attention to the process of development of the child and dismiss the right of children to attain a proper education. According to such children, Hakimova (2011:5) explains, children requiring for the special help, since small years take part in household, intellectual, physical and public work. The success of education of the pupils with lacks of physical and intellectual development is provided, first of all under condition of their psychological and practical preparation for work.

Failing students tend to be passive in thinking because they think that the business and their lives will significantly not be the same. This is why failing students are difficult to be developed. This mindset ought to be changed by providing opportunities for failing studentsin order to obtain an equal live welfare.

\section{METHOD}

This study is a survey study usingqualitative descriptive approach to discover the basic character of failing students based on their last education and other characters related to their life experiences since they fail to attend the school. A sampling of the study population used purposive sampling limited to failing students in junior high school and senior high school. The data then were obtained through observation and in-depth interviews using a structured questionnaire that covered and accompanied by disclosure of opportunity open as an initial data for the deepening the interview. The deepening of interviews was conducted on specific cases with informants parents as the coordinator of failing students in Kademangan District and Garum District Blitar, East Java.

\section{RESULTS AND DISCUSSION}

\section{A. Characteristic}

Based on the findings in the field, it is showed that the largest number of failing students respondents are children who have graduated from junior high school and did not proceed to a higher level.However, there are still many children who are not graduated from junior high school (droppingout in grade 8 and 9). The results of in-depth interviews show that their reason not to continue and give up their school is because they are more interested in working than studying in school.After dropping out of school, most of the respondents are anunaffiliated occupation. The results of in-depth interviews also showed that the type of work they choose arehodman andsand digging on the riverbank. While for the woman, the preferable working is shopkeepers (salesman) in stores around the area where he lived. The results of the field survey 
showed that the average education of the shopkeeper within the targeted area of research is junior high school education. A description of the dimensions of the entrepreneurial potential respondents is presented in Table 1.

Table1. Entrepreneurship Dimension Potency

\begin{tabular}{|c|c|c|c|}
\hline No & $\begin{array}{l}\text { Entrepreneurship } \\
\text { Dimension }\end{array}$ & Amount & $\begin{array}{l}\text { Percentage } \\
(\%)\end{array}$ \\
\hline 1 & \multirow{6}{*}{$\begin{array}{l}\text { Entrepreneurship } \\
\text { capability } \\
(39 \%)\end{array}$} & $\begin{array}{l}\text { Ability to face } \\
\text { uncertainty }\end{array}$ & 23 \\
\hline 2 & & $\begin{array}{l}\text { Respond towards } \\
\text { changes }\end{array}$ & 16 \\
\hline 3 & & $\begin{array}{l}\text { Creativity and } \\
\text { brand-new idea } \\
\text { implementation }\end{array}$ & 12 \\
\hline 4 & & $\begin{array}{l}\text { Insight on risk and } \\
\text { benefit }\end{array}$ & 37 \\
\hline \multirow[t]{2}{*}{5} & & $\begin{array}{l}\text { Life values } \\
\text { implementation }\end{array}$ & 12 \\
\hline & & Total & $100 \%$ \\
\hline 6 & \multirow{8}{*}{$\begin{array}{l}\text { Personality ability/ } \\
\text { Entrepreneurship } \\
\text { skill } \\
(44 \%)\end{array}$} & Innovation & 6 \\
\hline 7 & & Creativity & 18 \\
\hline 8 & & Risk management & 17 \\
\hline 9 & & Behaviour & 12 \\
\hline 110 & & Independency & 29 \\
\hline 11 & & Initiative & 11 \\
\hline 12 & & Responsibility & 7 \\
\hline & & Total & $100 \%$ \\
\hline 13 & \multirow[t]{7}{*}{$\begin{array}{l}\text { Other supporting } \\
\text { capability }(17 \%)\end{array}$} & $\begin{array}{l}\text { Communication and } \\
\text { negotiation }\end{array}$ & 19 \\
\hline 14 & & $\begin{array}{l}\text { Enterprises } \\
\text { management }\end{array}$ & 14 \\
\hline 15 & & Macroeconomy & 8 \\
\hline 16 & & Administration & 11 \\
\hline 17 & & Financial & 21 \\
\hline \multirow[t]{2}{*}{18} & & Marketing & 27 \\
\hline & & Total & $100 \%$ \\
\hline
\end{tabular}

The dimension of entrepreneurial potencyexposes personal potency of individual which is possible to be developed into an effective entrepreneurial spirit. The instruments are arranged in three dimensions, namely 1) the entrepreneurial capability is classified into five areas; 2) capability personality which is classified into seven aspects, and 3 ) the capability of supporting which is classified into six dimensions. Based on these instruments, it is known that the personality dimension is more prominent than the other dimensions. This illustrates that within the failing students the potential can be developed properly if it is done with a proper treatment. From the aspect of entrepreneurial capabilities, the insight over the risks of respondents is pretty good. This means that they are less afraid of taking a risks and can be a good capital to prospective entrepreneurs (Winarno, 2012).

From the dimensions of personality, the highest aspect is the independence of the respondents and followed by the respondent's creativity. While, in supporting capability dimension, particularly the opportunities of the ability to know the macroeconomic outlook is very low. However, the potential field of marketing and selling is quite good. Table 2 describes the personal experience of the respondents.

Table2. Informants Characteristic based on Individual Experiences

\begin{tabular}{|l|l|l|l|l|l|l|l|l|l|}
\hline No & Dimension & SS & S & TS & STS & $\begin{array}{l}\text { f SS } \\
(\%)\end{array}$ & $\begin{array}{l}\text { f S } \\
(\%)\end{array}$ & $\begin{array}{l}\text { f TS } \\
(\%)\end{array}$ & $\begin{array}{l}\text { f STS } \\
(\%)\end{array}$ \\
\hline 1 & Cleverness & 63 & 69 & 36 & 8 & $36 \%$ & $39 \%$ & $20 \%$ & $5 \%$ \\
\hline 2 & Interaction & 73 & 172 & 49 & 13 & $24 \%$ & $56 \%$ & $16 \%$ & $4 \%$ \\
\hline 3 & Personality & 51 & 115 & 80 & 17 & $19 \%$ & $44 \%$ & $30 \%$ & $6 \%$ \\
\hline 4 & $\begin{array}{l}\text { The entire } \\
\text { interaction }\end{array}$ & 61 & 201 & 74 & 15 & $17 \%$ & $57 \%$ & $21 \%$ & $4 \%$ \\
\hline
\end{tabular}

According to the table 2, the majority of respondents are more likely considered an average to slightly above average students during their education in school and possess the capability of interaction or good relationships with their peers. These findings explain that the cause of children out of school is not associated with the level of disability in receiving the lessons in school, but rather it is influenced by the external factors instead of their intelligence. This finding is interesting to be observed considering the average potential within the failing students which is possible to be developed. The ability of good interaction with their environment indicates that the level of their confidence or trust within the ability of individuals themselves (self-efficacy) can be developed if it is well-managed (Winarno, 2010).

\section{B. The Socio-cultural Circumstance of The Society}

According to the field observation, there are similarities in the case of failing students, the results of in-depth interviews with informants show that parents of failing students commonly do not provide a significant incentive for the continuation of their children's school. There are five (5) responses of parents when their child decided not to continue their school and it is listed in Table 3.

Table 3. The Parents' Responses regarding Failing Students

\begin{tabular}{|l|l|}
\hline $\begin{array}{l}\text { Informant } \\
\text { types }\end{array}$ & Parents' Response \\
\hline 1 & $\begin{array}{l}\text { I have asked and insisted my children go to } \\
\text { school but he/she did not want to. }\end{array}$ \\
\hline 2 & $\begin{array}{l}\text { At least I have advised and reminded my child } \\
\text { the importance of school }\end{array}$ \\
\hline 3 & $\begin{array}{l}\text { It is not a big deal when my children choose to } \\
\text { not continuing his/her school, it is a life choice. }\end{array}$ \\
\hline 4 & $\begin{array}{l}\text { The decision to not go to school is right in order } \\
\text { to alleviate the family's burden. The school } \\
\text { requires a lot of money only for transportation. }\end{array}$ \\
\hline 5 & $\begin{array}{l}\text { It is not a big deal to choose to work instead of } \\
\text { going to school. }\end{array}$ \\
\hline
\end{tabular}


Based on the variety of answers from the parents and in-depth observation failing students, it is understood that the average parental understanding of the function of education for children is deficient and they are very permissive to the child's decision to not attend formal education in school. Parents whose children decided not to continue their school tend to support the decision because the child will soon get a job in his village and earn income, and this is considered very helpful to the economic conditions of their households. From the other side, the moment there was no insistence it makes the children feel convenient for not going to school and working in the village to earn money and use it for their daily lives. Unfortunately, they even feel more comfortable because of obtaining money can make them satisfy than going to the school.

From the observation results, the information obtained expose that the progress of rural economy characterized by increasingly growing physical development activities, including the growth of rural businesses of trading, makes the children are able to find a job effortless. This is in line with the findings of Purnama (2014) who studied in Pontianak states that the cause of failing students is due to psychological factors of children or in other words, children are lazy to go to school. Related to the culture research conducted by Rahmanto (2010), he discovers that the factors of failing students within Blitar, East Java is because of the internal factors, i.e. low income and level of education the head of the family. Further, this reason is also supported by the external factors, particularly the distance to the formal school and the cultures around the children which disincentivise the motivation of children to pursue education. It is also consistent with research Septiana\&Wulandari (2012), Grahacendikia (2009), Alifianto (2008)) who discovered the cause of failing students and school's responses as well as the environmental factors and the psychological state of individuals that have an impact on the attitudes and behaviors in deciding to give up their school. The psychological condition is associated with a source of self-control or locus of control, selfconcept, and self-value.

\section{CONCLUSION AND SUGGESTION}

\section{Conclusion}

According to the aforementioned findings and discussion, it can be concluded that most the failing students only possess junior high school degree and it is mostly motivated by the socio-cultural circumstance and economic development within the rural area. In terms of economic development in the rural area, it can be stated that currently, the demand of worker is increasing. Therefore, it disincentives their motivation to pursue an education in school. However, the potency of failing students to be developed as an entrepreneur is positive. This is due to their experience during their absence in the school. It can be concluded that the failing students are possible to be entrepreneurship since their potency is available.

\section{Suggestion}

In order to avoid the increasing number of failing students, the governmentneeds to take into account intensively the understanding of parents regarding the importance of education. The government also need to concern on the establishment of high school within therural area in order to facilitate the local community. Further, it is suggested to impose higher requirement in job vacancy, therefore, the local community will be motivated to seek high education.

\section{REFERENCES}

Alifianto, A. 2008. Kuliah Kerja Nyata: Wajib Belajar 9 Tahun. URL:http://www.perwatakabarindonesia.blog. spot.com/

Graha Cendikia. 2009. Anak Putus Sekolah dan Cara Pembinaannya.

URL:http://www.google.co.id/putussekolah/re ferensipenelitianskripsi-tesis.

Hakimova, Muhbbat. 2011. Ways of Professional Training of Children with The Limitted Opportunities dalam Social and Natural Sciences Journal. Vol. 4. ISSN 1804-4158.

Hansemark, O.C. 1998. The Effects Of An Entrepreneurship Programme On Need Forachievement And Locus Of Control Of Reinforcement dalam International Journal of Entrepreneurship Behaviour and Research, 4(1): 28-50.

Kuratko D.F. 2003. Entrepreneurship Education:Emergin Trends And Challenger for The 21 Centure, The Entreprenuership Program,dkuratko@bsu.edu.

Lubis, Ratna Indawati. 2014. ” Student's Entrepreneurial Strategy: Connecting Minds?" dalam International Journal of Arts \& Sciences. 07(03): 545-568. ISSN: 1944-6934.

Purnama, DT. 2014. Fenomena Anak Putus Sekolah dan Faktor Penyebabnya di Pontianak dalam Sociologique, Vol. 2 Desember 2014. 
Rahmanto,GP Karakteristik keluarg yang mempunyai anak tidak melanjutkan sekolah ke SMA di Kecamatan Panggungrejo Kabupaten Blitar.

Septiana, Liska \& Wulandari, Sri Pingit. 2012. Pemodelan Remaja Putus Sekolah Usia SMA di Propinsi Jawa Timur dengan Menggunakan Metode Regresi Spasial. Skripsi.

Sipitanou, Athina A. and Papagiannis, George D. 2013. Education, Entrepreneurship and Entrepreneurial Activation: A Challenge for All dalam International Journal of Arts \& Sciences. ISSN: 1944-6934: 6(2): 139-149 (2013).

Winarno,A. 2010. Pendidikan Kewirausahaan Berbasis Nilai, Putra Media Nusantara, Surabaya.

Winarno,A. 2012. Efektifitas pendidikan Kewirausahaan di Jawa Timur, penelitian survey, tidak diterbitkan.

Winarno,A. 2012. Intensi Kewirausahaan: Perspektif Karakteristik Kepribadianm, Pembelajaran an Jaringan sosial (studi pada mahasiswa Program Akademik dan Vokasi UM). Jurnal Ekonomi Bisnis tahun 17 nomor 1 Maret 2012 hal $67-78$. 